\title{
It's Not About Their Citizenship, it's About Ours
}

\author{
Vesco Paskalev
}

The very passion and fury pouring from Christian Joppke's contribution should prompt both the lawyer and the political philosopher that he is wrong. I too am outraged by what ISIS fighters are doing, but it is well known that the function of constitutional rights, and of the constitutions themselves, is precisely to assure that the legislator is not driven by the passion of the day. One decade after 9/11 we know that the actions taken both by the President and the Congress of the US, based on the rationale that it is a new world that we have woken up into, were not all reasonable, to put it mildly. So may be today's rush to strip terrorist suspects of their citizenship. When watching the daily news on TV, one is easily tempted to think that we are living in extraordinarily dangerous times, which warrant a return to what the US Supreme Court considered to be 'cruel punishment' half a century ago. Yet as a matter of statistics, and despite our contrary impressions, violence of all kinds in the world is actually declining. ${ }^{1}$ On the other hand, the capacity of law enforcement agencies for surveillance and control, especially in the OECD countries, has increased dramatically, so the return to practices which have long been abandoned is difficult to justify. This is not to say that that citizenship is a sacred cow and any return to abandoned practices is excluded by some historic laws of human progress. Nothing can be further from the truth. But it does follow that the proponents of banishment must provide a more subtle justification than we have seen so far.

Joppke has a point when distinguishing the old school revolutionaries from the contemporary jihadists, who conceive of themselves as members of the global ummah, and not of any state. (Do we know that for sure? ISIS aims to create an Islamic state after all). He also has a point that waging war against a country is a good reason to strip the warrior of the citizenship of that country. I can accept even stretching this argument to apply to all those who take up arms against any allies of that country, or even to those who

1 Pinker, S. (2011), The Better Angels of our Nature. New York: Viking.

(C) The Author(s) 2018

R. Bauböck (ed.), Debating Transformations of National Citizenship,

IMISCOE Research Series,

https://doi.org/10.1007/978-3-319-92719-0_35 
have taken arms against the international system of states. This would bring me already quite close to the position of the 'deprivationists'.

What I find difficult to accept is the unquestioned assumption that this gesture would serve any of the goals Joppke, and the politicians favouring banishment, may have. If the jihadists were as cosmopolitan as he takes them to be, deprivation would not have any meaning, neither for the actual fighters, nor for any like-minded followers. It might be the case that taking their passport will have the practical effect of preventing them from travelling to Syria or back, but as a person who is genuinely outraged by their deeds, I would rather see them locked up in prison rather than left at large in a legal limbo (in the Middle East out of all places!). For Joppke the practical side is only of secondary concern, but I am afraid his theoretical argument is self-defeating.

Now, if we accept that the jihadists just do not care if they are deprived of their western citizenships, let us consider whether this would still matter for anyone else. On the one hand, there are the 'normal' citizens of the same country who may wish to see the extremists publicly excommunicated. This is a legitimate concern. However, it is in no way different from the desire of many law-abiding citizens to see murderers and rapists sent to the electric chair. So the usual objections to the latter punishments apply here too. More importantly, while there is some commensurability between a murder and a death sentence, the very gravity of the offences of the jihadists make citizenship deprivation superfluous. Ironically, not the cruelty of citizenship deprivation, but its softness make it appear quite inappropriate for the case of terrorists. If we take into account also the practical difficulties arising in the prosecution of a foreigner, on balance it might be better to keep him as a citizen. On the other hand, the possibility or impossibility of revocation defines and redefines the meaning of the concept of citizenship itself - of our citizenship, not of theirs. That is why many academics, whose professional duty is to care for precisely such nuance, are so uneasy about the recent trend. I would be glad if this concern remains confined to the ivory towers of the academia, but I suspect that the conditionality of citizenship is more than a theoretical concern for those citizens who are not white, Anglo-Saxon and Christian and have only recently arrived from the wrong side of the OECD border.

One may argue, as Peter Schuck does, for deprivation administered under narrowly circumscribed conditions. Indeed, due process can alleviate some of the anxieties the conditionality of citizenship would create, but he does not provide much of a justification for this conditionality in the first place. He also relies on the intuitive, yet questionable assumption that citizenship 
deprivation serves to protect the state and its people. But all grounds for deprivation he suggests already constitute a serious crime, and if the perpetrator must be convicted to be denationalised as he suggests, then again, what difference would it make if those imprisoned for a very long time remain citizens or not? If deprivation were administered properly - for grave crimes and with due process, it becomes redundant.

Beyond these conceptual concerns, and paying due consideration to the all too present terrorist threats, I want the Islamic State bombed out of existence, and I want all jihadists punished for what they do. But as a citizen I also want my tax money spent on police to put the bad apples in jail, not on border patrols to keep them out.

Open Access This chapter is licensed under the terms of the Creative Commons Attribution 4.0 International License (http://creativecommons.org/licenses/by/4.0/), which permits use, sharing, adaptation, distribution and reproduction in any medium or format, as long as you give appropriate credit to the original author(s) and the source, provide a link to the Creative Commons license and indicate if changes were made.

The images or other third party material in this chapter are included in the chapter's Creative Commons license, unless indicated otherwise in a credit line to the material. If material is not included in the chapter's Creative Commons license and your intended use is not permitted by statutory regulation or exceeds the permitted use, you will need to obtain permission directly from the copyright holder.

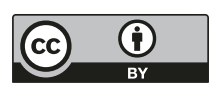

